\title{
EFFECT OF MATRICARIA RECUTITA L. AS FOOD ADDITIVES ON THE PRODUCTIVITY OF SILKWORM, BOMBYX MORI L. Nagat H. Soliman
}

Plant Protection Department, Faculty of Agriculture, Fayoum University, Egypt.

\begin{abstract}
The present work was carried out at Plant Protec. Dept. Fac. of Agric., Fayoum Univ. during spring season of 2019 to study the effect of Matricaria recutita as food additives on some characteristics of silkworm, Bombyx mori L. Dried flowers of $M$. recutita were crushed and dissolved in distilled water to prepare different concentrations $(0.1,0.2,0.3$ and $0.4 \mathrm{mg} / \mathrm{ml}$.). Results showed that, the larval mortality $\%$ of $B$. mori fed on mulberry leaves sprayed with different concentrations of $M$. recutita decreased with increasing each of concentrations and the stages of the larvae. On the contrary, the mean weights of each of the $5^{\text {th }}$ instar larvae and pupae, increased with increasing concentrations with significant differences between treatment and control. For the duration of the $5^{\text {th }}$ instar larvae, statistical analysis proved that there were significant differences between treatments. The means of, cocoon weights, cocoon shell weights and cocoon shell ratio, increased with increasing concentrations. Statistical analysis proved that there were significant differences between $0.4 \mathrm{mg} . / \mathrm{ml}$. concentration and each of other concentrations and control.
\end{abstract}

\section{INTRODUCTION}

The silkworm Bombyx mori L. is a mono phytophagous insect feeding on mulberry leaves. The silk industry plays an important role in the economy, so research on silkworm and mulberry crop enhancement is of high importance. Fortification of mulberry leaves with certain nutritive materials as carbohydrates, amino acids, proteins, lipids, antibiotics, vitamins, enzymes, minerals and other chemicals have proved to be useful for improving crop yield (Rajegowda 2002). Pharmacological studies have acknowledged the value of medicinal plants as potential source of bioactive compounds (Prusti et al., 2008). Matricaria recutita L. is aromatic and medicinal plant . A total of 120 chemical constituents have been identified in $M$. recutita, including terpenoids (chamazulene), flavonoids (apigenin and luteolin), and coumarins (umbelliferone, alpha-bisabolol). The flavonoids apigenin and luteolin possess anti-inflammatory, carminative, and antispasmodic properties (Zadeh et al., 2016). The present study was carried out to determine the effect of $M$. recutita as food additives on the productivity of silkworm , B. mori.

\section{MATERIALS AND METHODS}

Evaluation of Matricaria recutita as food additives on the productivity of silkworm, Bombyx mori was studied during spring season of 2019 at Plant Protec. Dept. Fac. of Agric., El Fayoum Univ. Dried flowers of $M$. recutita were crushed

Fayoum J. Agric. Res. \& Dev., Vol. 34, No.1, January, 2020 
and dissolved in distilled water to prepare different concentrations $(0.1,0.2,0.3$ and $0.4 \mathrm{mg} / \mathrm{ml}$.). Egg box of silkworm, B. mori (Egyptian hybrid) were obtained from the Seric. Res. Dept., Plant Protec. Res. Inst, Agric. Res. Center. Dokki, Giza. Newly hatched larvae of $B$. mori were reared on fresh mulberry leaves (Morus alba var. indicia) under laboratory conditions $\left(27 \pm 2^{\circ} \mathrm{C}, 76 \pm 5 \% \mathrm{RH}\right)$. Mulberry leaves were obtained from Mulberry trees grown in the farm of Faculty of Agriculture at Fayoum (at Dar El Ramd region ). At the beginning of the $\mathbf{1}^{\text {st }}$ instar, larvae were divided into five groups, each of 50 larvae. Each group was divided into five replicates.

For treatment, mulberry leaves sprayed with different concentrations $(0.1$, $0.2,0.3$ and $0.4 \mathrm{mg} / \mathrm{ml}$.) of $M$. recutita after drying on ambient air temperature for one minute. The larvae of control fed on mulberry leaves sprayed with distilled water. The characteristics of $B$. mori, namely, the $5^{\text {th }}$ instar larval weights, larval durations, mortality percentages, pupal weights, cocoon weights, cocoon shell weights and cocoon shell ratio were recorded.

Statistical analysis

Data was analyzed by ANOVA through statistical package for social science (SPSS) to find out the significance between treated and control (Berkowitz and Allaway 1998). Means were separated by (L.S.D at $0.05 \%$ ).

\section{RESULTS AND DISCUSSION}

Table (1) illustrates that the larval mortality $\%$ of $B$. mori fed on mulberry leaves sprayed with different concentrations of $M$. recutita decreased with increasing each of concentrations and the stages of the larvae. The mortality $\%$ of the $1^{\text {st }}$ instar larvae, were $13,33,13,20,12,45$ and $10,90 \%$ for $0.1,0.2,0.3$ and 0.4 concentrations, respectively, compared with $14.67 \%$ for control. For the $5^{\text {th }}$ instar larvae the mortality $\%$ were $6.29,6.09,6.1$ and $5.11 \%$, for the same concentrations, respectively compared with $6.50 \%$ for control. Statistical analysis proved that there were significant differences between $0.4 \mathrm{mg} . / \mathrm{ml}$. concentration and each of other concentrations and control. The obtained results are in general agreement with the findings of Murugesh and Bhaskar, (2007) when used mulberry leaves treated with aqueous extract of Parthenium hysterophorus, Tridax procumbens and Tribulus terrestris on $5^{\text {th }}$ instar mortality percentages of B. mori. Samba, et al., (2016) when used aqueous extract of Azadirachta indica, Parthenium hysterophorus, Osimum sanctum and Pongamia pinnata.

Fayoum J. Agric. Res. \& Dev., Vol. 34, No.1, January, 2020 
EFFECT OF MATRICARIA RECUTITA L. ................................. 44

TABLE (1) Effect of mulberry leaves treated with Matricaria recutita on mortality percentages of silkworm, Bombyx mori $\mathrm{L}$.

\begin{tabular}{|c|c|c|c|c|c|}
\hline \multirow{2}{*}{$\begin{array}{c}\text { Concentrations } \\
(\mathbf{m g} / \mathbf{m l} .)\end{array}$} & \multicolumn{5}{|c|}{ Mortality percentages } \\
\cline { 2 - 6 } & $\mathbf{1}^{\text {st }}$ instar) & $\mathbf{2}^{\text {nd }}$ instar & $\mathbf{3}^{\text {rd }}$ instar & $\mathbf{4}^{\text {th }}$ instar & $\mathbf{5}^{\text {th }}$ instar \\
\hline 0.1 & $13.33 \pm 0.2680$ & $11.22 \pm 0.4323$ & $9.88 \pm 0.4332$ & $7.62 \pm 0.5550$ & $6.29 \pm 0.0600$ \\
\hline 0.2 & $13.20 \pm 0.2132$ & $11.90 \pm 0.3221$ & $9.20 \pm 0.4000$ & $6.00 \pm 0.4766$ & $6.09 \pm 0.1900$ \\
\hline 0.3 & $12.45 \pm 0.2344$ & $10.56 \pm 0.7554$ & $8.00 \pm 0.2333$ & $6.23 \pm 0.3556$ & $6.10 \pm 0.1908$ \\
\hline 0.4 & $10.90 \pm 0.66332$ & $10.22 \pm 0.4332$ & $7.05 \pm 0.3442$ & $6.40 \pm 0.7483$ & $5.11 \pm 0.1123$ \\
\hline control & $14.67 \pm 0.2300$ & $12.55 \pm 0.50990$ & $9.00 \pm 0.5667$ & $8.43 \pm 0.4100$ & $6.50 \pm 0.0990$ \\
\hline F value & $* *$ & $*$ & - & $*$ & $*$ \\
\hline LSD at 0.05\% & 1.566 & 1.787 & - & 1.500 & 0.444 \\
\hline
\end{tabular}

According to data in Table (2) the mean weights of the $5^{\text {th }}$ instar larvae fed on mulberry leaves sprayed with different concentrations of $M$. recutita, as well as pupal weights, increased with increasing concentrations. The mean weights of the $5^{\text {th }}$ instar larvae were, 2.011, 2.107, 2.150 and $2.300 \mathrm{~g}$., for concentrations of 0.1 , $0.2,0.3$ and 0.4 , respectively, compared with $2.001 \mathrm{~g}$. for control, with significant differences between $0.4 \mathrm{mg} . / \mathrm{ml}$. concentration and each of other concentrations and control. For pupal weights, they were $0.780,0.800,0.805$ and $0.829 \mathrm{~g}$. for the same concentrations, respectively, compared with $0.713 \mathrm{~g}$. for control, with significant differences between treatment and control . For the $5^{\text {th }}$ instar larval durations, they were, $239.69,240.36,243.36$ and $240.36 \mathrm{~h}$. for the same concentrations, respectively, compared with $244.32 \mathrm{~h}$. for control. Statistical analysis proved that there were significant differences between treatments.

The obtained results are in general agreement with the findings of many authors who found that improving in weights of B. mori larvae and larval duration when using mulberry leaves treated with amlaki rasayan (Madhuri and Jitendra, 2002) ; mulberry leaves treated with aqueous extract of Withania somnifera (Sridevi et al, 2004) and with Kuntamalla and Rao, (2005) when used mulberry leaves treated with Azadirachta indica. The obtained results are also in general agreement the findings of many authors who found that increasing in pupal weights of B. mori when used mulberry leaves treated with Coffea Arabica, (Jeyapaul $\boldsymbol{e t}$ al., 2003); mulberry leaves treated with aqueous extract of Nephrolepis auriculata, Christella parasitica, Dicranopteris linearis and Pityrogramma calomelanos (Padmalatha et al., 2005); mulberry leaves treated with aqueous extract of Murraya koenigii (Ganesan and Isaiarasu, 2007) and Samba, et al.,( 2016) when used aqueous extract of Azadirachta indica, Parthenium hysterophorus, Osimum sanctum and Pongamia pinnata.

Fayoum J. Agric. Res. \& Dev., Vol. 34, No.1, January, 2020 
Nagat H. Soliman

TABLE (2)Effect of mulberry leaves treated with concentrations of Matricaria recutita on some biological parameters of silkworm, Bombyx mori $\mathrm{L}$.

\begin{tabular}{|c|c|c|c|}
\hline \multirow{2}{*}{$\begin{array}{c}\text { Concentrations } \\
(\mathbf{m g} / \mathbf{m l} .)\end{array}$} & \multicolumn{3}{|c|}{ Parameters } \\
\cline { 2 - 4 } & $\mathbf{5}^{\text {th }}$ instar larval & $\begin{array}{c}\mathbf{5}^{\text {th }} \text { instar larval } \\
\text { durations (hours) }\end{array}$ & $\begin{array}{c}\text { Pupal weights } \\
(\mathbf{g})\end{array}$ \\
\hline 0.1 & $2.011 \pm 0.0500$ & $239.69 \pm 0.0877$ & $0.780 \pm 0.0332$ \\
\hline 0.2 & $2.107 \pm 0.1120$ & $240.36 \pm 0.0680$ & $0.800 \pm 0.0202$ \\
\hline 0.3 & $2.150 \pm 0.0890$ & $243.36 \pm 0.0110$ & $0.805 \pm 0.0321$ \\
\hline 0.4 & $2.300 \pm 0.0980$ & $240.36 \pm 0.0677$ & $0.829 \pm 0.0554$ \\
\hline control & $2.001 \pm 0.0999$ & $244.32 \pm 0.0433$ & $0.713 \pm 0.0444$ \\
\hline F value & $* *$ & $\ldots$. & $*$ \\
\hline LSD at 0.05\% & 0.032 & 0.140 & 0.069 \\
\hline
\end{tabular}

Data in Table (3) indicate that, the means of each of the cocoon weights, cocoon shell weights and cocoon shell ratio, increased with increasing concentrations. The mean weights of the cocoon weights were, 1.054, 1.066, 1.090 and 1.276 for the concentrations of $0.1,0.2,0.3$ and $0.4 \mathrm{mg} / \mathrm{ml}$, respectively, compared with $2.001 \mathrm{~g}$. for control.

For cocoon shell weights, they were $0.187,0.195,0.203$ and $250 \mathrm{~g}$ for the same concentrations, respectively, compared with $0.188 \mathrm{~g}$ for control.

For cocoon shell ratio, they were, $17.93,18.29,18.62$ and $19.59 \%$ for the same concentrations, respectively, compared with18.76 for control. For the previous parameters, Statistical analysis proved that there were significant differences between $0.4 \mathrm{mg} . / \mathrm{ml}$. concentration and each of other concentrations and control.

The obtained results are in general agreement with the findings of many authors who found that increasing in cocoon weights, cocoon shell weights and cocoon shell ratio of $B$. mori when used mulberry leaves treated with amlaki rasayan (Madhuri and Jitendra, 2002), mulberry leaves treated with aqueous extract of Coffea Arabica, (Jeyapaul et al., 2003), mulberry leaves treated with aqueous extract of Azadirachta indica, (Kuntamalla and Rao, 2005), mulberry leaves treated with aqueous extract of Murraya koenigii, (Ganesan and Isaiarasu, 2007), mulberry leaves treated with aqueous extract of Lantana camera and Ocimum sanctum, (Sumathi, 2008) and mulberry leaves treated with aqueous extract of Andrographis panciculata and Plumbago zeylanica, (Takhlique, 2011).

Fayoum J. Agric. Res. \& Dev., Vol. 34, No.1, January, 2020 
EFFECT OF MATRICARIA RECUTITA L.

TABLE (3)Effect of treated mulberry leaves with concentrations of Matricaria recutita on cocoon indices of silkworm, Bombyx mori $\mathrm{L}$.

\begin{tabular}{|c|c|c|c|}
\hline \multirow{2}{*}{$\begin{array}{c}\text { Concentrations } \\
(\mathrm{mg} / \mathrm{ml} .)\end{array}$} & \multicolumn{3}{|c|}{ Parameters } \\
\hline & $\begin{array}{c}\text { Cocoon weights } \\
\text { (g) }\end{array}$ & $\begin{array}{c}\text { Cocoon shell } \\
\text { weights (g) }\end{array}$ & $\begin{array}{c}\text { Cocoon shell } \\
\text { ratio }(\%)\end{array}$ \\
\hline 0.1 & $1.054 \pm 0.0311$ & $0.187 \pm 0.0122$ & $17.93 \pm 0.2000$ \\
\hline 0.2 & $1.066 \pm 0.0422$ & $0.195 \pm 0.0100$ & $18.29 \pm 0.2010$ \\
\hline 0.3 & $1.090 \pm 0.0200$ & $0.203 \pm 0.0122$ & $18.62 \pm 0.2000$ \\
\hline 0.4 & $1.276 \pm 0.0201$ & $0.250 \pm 0.0140$ & $19.59 \pm 0.1544$ \\
\hline control & $1.002 \pm 0.0300$ & $0.188 \pm 0.0120$ & $18.76 \pm 0.1988$ \\
\hline F value & $* *$ & $* *$ & $* *$ \\
\hline LSD at $0.05 \%$ & 0.088 & 0.050 & 0.599 \\
\hline
\end{tabular}

\section{REFERENCES}

Adhithya, R. and Manimegalai, S. (2010). Antibacterial activity of plant extracts against diseases of Bombyx mori L. Madras Agricultural Journal. 97 : 7 / 9, 285- 2286.

Berkowitz, D. and Allaway, A. (1998). Statistical package for social sciences (SPSS), Version 7.5 for Windows NT/Windows 95, 130-132.

Ganesan, R. and Isaiarasu, G. (2007). Effect of the curry leaf extract on growth and cocoon characteristics of Bombyx mori L. Journal of Ecotoxicology \& Environmental Monitoring. 17: 3, 281-284.

Jeyapaul, C.; Padmalatha, C.; Singh, A. ; Murugesan, A. G. and Dhasarathan, P. (2003). Effect of plant extracts on nutritional efficiency in mulberry silkworm Bombyx mori L. Indian Journal of Sericulture. 42: 2, 128131.

Kuntamalla, S. and Rao, A. P. (2005). Influence of alcoholic macerative of neem flowers in the management of flacherie disease and economical parameters of silkworm, Bombyx mori L. Biochemical and Cellular Archives. 5: 1, 89-95.

Madhuri, D. and Jitendra, G. (2002). Application of plant extract based ayurvedic medicines with feed to the silkworm Bombyx mori L. nistari race to assess its effect on cocoon production. Environment and Ecology. 20: 3, 505-510.

Murugesh, K. A. and Bhaskar, R. N. (2007). Efficacy of botanicals on larval growth of silkworm, Bombyx mori L. and its impact on silk productivity. Bulletin of Indian Academy of Sericulture.1: 1, 11-15.

Padmalatha, C.; Rajakumari, D. V. ; Jeyapaul, C. and Ranjitsingh, A. J. (2005). Growth promoting effect of ferns on Bombyx mori L. Indian Journal of Sericulture. 44: 2, 218-220.

Fayoum J. Agric. Res. \& Dev., Vol. 34, No.1, January, 2020 
Nagat H. Soliman

Prusti, A.; Mishra, S.R. ; Sahoo, S. and Mishra, S.K. (2008). Antimicrobial activity of some Indian Medicinal Plants. Ethnobot. Leaflets, 12: 227-230.

Rajegowda, R. (2002). Impact of seriproon cocoon production and productivity in silkworm, Bombyx mori L. Proceeding, National Confer. on strategies for Sericultures Research and Develop, (CSR\&TI) Mysore, Indian, 264-266.

Samba, N. A.; Srinivas, N. B. and M. Jagadish N.(2016). Screening of medicinal plant extracts against Beauveria bassiana infection to $\mathrm{v}^{\text {th }}$ instar larvae of Bombyx mori L. European Journal Of Pharmaceutical and Medical Research,3(4):549-553.

Sridevi, G.; Bhaskar, R. N.; Devaiah, M. C.; Govindan, R.; Vasundhara, M. and Geetha, K. R.(2004). Effect of medicinal plant extracts on rearing parameters of silkworm Bombyx mori L. (PM x $\left.\mathrm{CSR}_{2}\right)$. Bulletin of Indian Academy of Sericulture. 8: 2, 22-29.

Sumathi, S. (2008). Supplementation of plant extracts on economic parameters of silkworm Bombyx mori L. Journal of Ecotoxicology \& Environmental Monitoring. 18: 5, 445-450.

Takhlique, M. (2011). Medicinal plant extracts a great determinant to economic potency of silkworm: Bombyx mori L. Journal of Entomological Research. 35: 3, 231-233.

Zadeh , J. B.; Nasroallah, M. K. and Zahra, M. K. (2014). Chamomile (Matricaria recutita) as a valuable medicinal plant. International journal of Advanced Biological and Biomedical Research. 2( 3): 823-829.

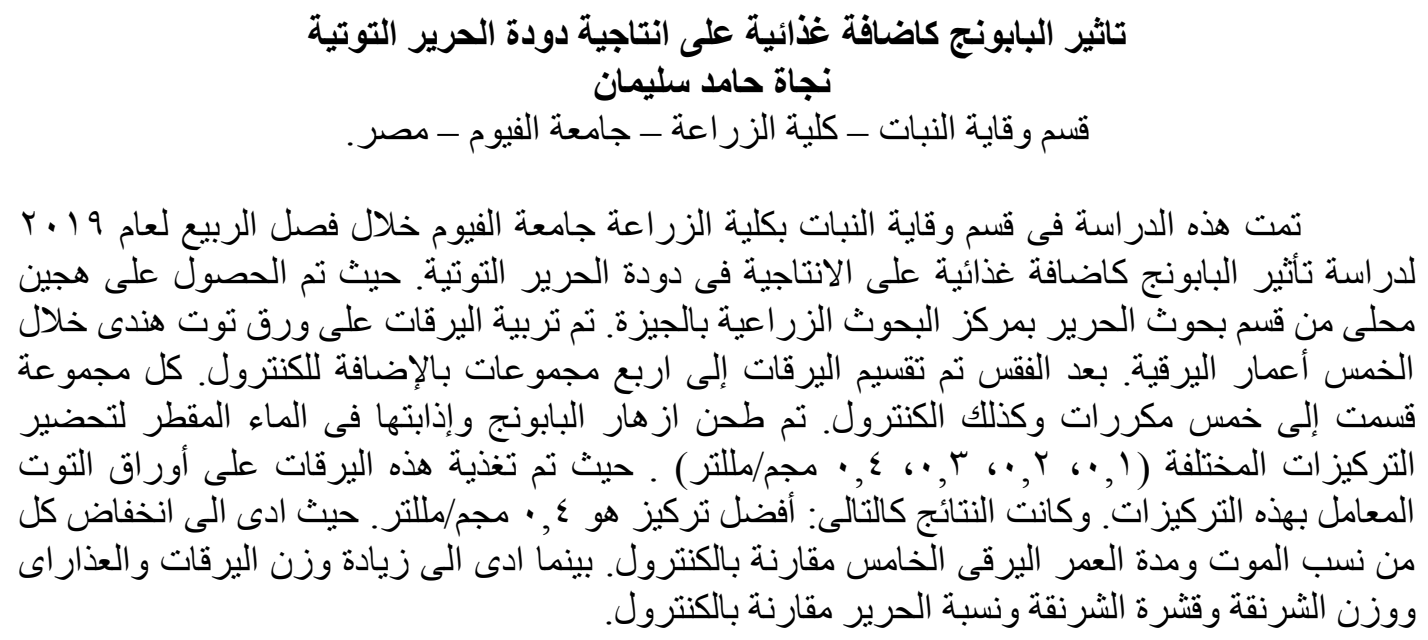

Fayoum J. Agric. Res. \& Dev., Vol. 34, No.1, January, 2020 